\title{
RECOGNIZING THE FAMINE EARLY WARNING SYSTEMS NETWORK Over 30 Years of Drought Early Warning Science Advances and Partnerships Promoting Global Food Security
}

\author{
Chris Funk, Shraddhanand Shukla, Wassila Mamadou Thiaw, James Rowland, Andrew Hoell, \\ Amy McNally, Gregory Husak, Nicholas Novella, Michael Budde, Christa Peters-Lidard, \\ Aklhalil Adoum, Gideon Galu, Diriba Korecha, Tamuka Magadzire, Mario Rodriguez, \\ Miliaritiana Robjhon, Endalkachew Bekele, Kristi Arsenault, Pete Peterson, Laura Harrison, \\ Steven Fuhrman, Frank Davenport, Marty Landsfeld, Diego Pedreros, Jossy P. Jacob, \\ Curt Reynolds, Inbal Becker-Reshef, and James Verdin
}

For over 30 years, the interagency FEWS NET team has been on the cutting edge of drought early warning science, informing food security outlooks that save lives and livelihoods in high-risk countries.

I n 2018, hunger and the specter of famine continue to loom large on the global stage, contributing to severe malnutrition; stunted, wasted, and lowbirthweight children; poor health; and lost productivity (FAO et al. 2017). Roughly 1 in 10 people are undernourished (821 million) and chronic hunger has increased substantially since 2015 due to the combined effects of poverty, conflict, and a more extreme climate (FAO et al. 2017). According to estimates from the Famine Early Warning Systems Network (FEWS NET; www.fews.net), more than 83 million people faced crisis conditions requiring food assistance in 2018-75\% more than in 2015 (FEWS NET 2018). Fortunately, international aid agencies, national disaster risk management systems, and nongovernmental organizations (Table 1) can often provide effective humanitarian relief by identifying and targeting the most food-insecure populations for assistance. In 2017, the U.S. Agency for International Development's Office of Food For Peace (USAID FFP) reached 70 million beneficiaries with $\$ 3.6$ billion in food aid, cash transfers, or food vouchers (FFP 2018). Accurate and timely early warning can increase the productivity and efficiency of this assistance, helping to ensure that finite aid resources are directed to the right people before there is widespread malnutrition and starvation. Numerous national and international early warning systems (Table 2) support the early identification of emerging droughts and food crises. Originally formed in response to the Sahel droughts of 1984 and 1985 (Brown 2008), more than 30 years of continuous refinement has allowed FEWS NET to develop into one of the most sophisticated monitoring

Publisher's Note: This article was modified on 25 June 2019 to acknowledge a funding grant. 
TABLE I. A nonexhaustive list of donors and implementers of humanitarian assistance.

\begin{tabular}{|ll|}
\hline Agencylorganization & Website \\
\hline World Food Programme & www.wfp.org \\
\hline USAID Food For Peace & $\begin{array}{l}\text { www.usaid.gov/who-we-are/organization/bureaus/bureau } \\
\text {-democracy-conflict-and-humanitarian-assistance/office-food }\end{array}$ \\
\hline European Commission & https://ec.europa.eu/echo/themes/food-assistance_en \\
\hline Japan International Cooperation System & www.jics.or.jp/jics_html-e/activities/grant/kr/index.html \\
\hline United Nations International Children's Emergency Fund & www.unicef.org/what-we-do \\
\hline Oxford Committee for Famine Relief & www.oxfam.org \\
\hline Action Against Hunger & www.actionagainsthunger.org/ \\
\hline CARE & www.care.org/ \\
\hline
\end{tabular}

systems. ${ }^{1}$ Within FEWS NET, an interagency and interdisciplinary team has developed a cuttingedge Drought Early Warning System (DEWS) that anticipates and tracks climate-related hazards and shocks (Table 3). This paper provides, for the first time, an up-to-date description of the strategies and components of the current FEWS NET DEWS, along with several real-world examples demonstrating how this system is helping to save lives and secure livelihoods.

Global food security rests on four pillars: adequate food availability, food access, and food utilization, accompanied by stable prices and incomes (M. E. Brown et al. 2015). Famines occur when impoverished individuals cannot afford to purchase or otherwise access adequate quantities of nutritious food (Sen 1981). These crises, however, are often precipitated by conflict and/or climate extremes, and both conflict and climate have driven the recent, rapid rise in food insecurity (FAO et al. 2017). Droughts can disrupt all four food security pillars. Lost farm revenues and rising prices can limit access and reduce local availability. Low levels of runoff can lead to poor drinking-water quality, disease, and reduced nutrition. And regional drought impacts can destabilize regional food systems, altering imports and exports, which, in turn, increases prices. Thus, FEWS NET includes food security-focused DEWS linked to a highly developed analytical framework that seeks the rapid identification of emerging crisislevel outbreaks of acute food insecurity (Fig. 1a). ${ }^{2}$

Through the regular development of subnationalscale scenarios, FEWS NET identifies the location, extent, severity, and causes of food insecurity. Such scenario development requires the adoption of working assumptions in a number of areas, including

\footnotetext{
${ }^{1}$ We would like to acknowledge the excellent work being done by all the systems and agencies listed in Tables 1 and 2 . Our objective in this study is not to compare FEWS NET with other systems, but rather provide an accessible description of FEWS NET's climate and weather-related activities and early warning strategy.

${ }^{2}$ FEWS NET currently monitors 22 countries in Africa along with Afghanistan, Yemen, Haiti, and Central America.
}

AfFILIATIONS: FUnK AND PEDREROs-Earth Resources Observation and Science Center, U.S. Geological Survey, Sioux Falls, South Dakota, and Climate Hazards Center, University of California, Santa Barbara, Santa Barbara, California; ShukLa, Husak, Peterson, HaRrison, DaVenPort, ANd LANDSFeld-Climate Hazards Center, University of California, Santa Barbara, Santa Barbara, California; Thiaw, Novella, Robjhon, Bekele, and Fuhrman-NOAA/Climate Prediction Center, College Park, Maryland; Rowland AND BUDDEEarth Resources Observation and Science Center, U.S. Geological Survey, Sioux Falls, South Dakota; HoElL-Physical Sciences Division, NOAA/Earth System Research Laboratory, Boulder, Colorado; McNally and Peters-Lidard—NASA Goddard Space Flight Center, Greenbelt, Maryland; Adoum, Galu, Korecha, Magadzire, AND RodrIGUez-Climate Hazards Center, University of California, Santa Barbara, and Famine Early Warning Systems Network, Santa Barbara,
California; ARSENAULt AND JACOB—NASA Goddard Space Flight Center, and Science Applications International Corporation, Inc., Greenbelt, Maryland; ReYNOLDS-U.S. Department of Agriculture, Washington, D.C.; BeCKER-Reshef-University of Maryland, College Park, College Park, Maryland; Verdin-Office of Food for Peace, U.S. Agency for International Development, Washington, D.C. CORRESPONDING AUTHOR: Chris Funk, cfunk@usgs.gov

The abstract for this article can be found in this issue, following the table of contents. DOI:10.1175/BAMS-D-17-0233.I

A supplement to this article is available online (I0.II75/BAMS-D-I7-0233.2).

In final form 29 December 2018

(C)2019 American Meteorological Society

For information regarding reuse of this content and general copyright information, consult the AMS Copyright Policy. 
TABLE 2. A nonexhaustive list of agencies providing food security and drought early warning services.

\section{Agencylorganization}

\section{Food Security Early Warning and Crop Monitoring}

FEWS NET

WFP Food Security Analysis

United Nations Office for the Coordination of Humanitarian Affairs

Integrated Food Security Phase Classification (IPC) Global Platform

UN FAO-Global Information and Early Warning System

European Commission Monitoring Agricultural ResourceS (MARS)

Group on Earth Observations - Crop Monitor for Early Warning

Asian Rice Crop Estimation and Monitoring (Asia-RiCE)

South Africa Agricultural Research Council

USDA Foreign Agricultural Service

European Drought Observatory

\section{Website}

www.fews.net

http://vam.wfp.org/

www.unocha.org/

www.ipcinfo.org/

www.fao.org/giews/en/

https://ec.europa.eu/jrc/en/mars

www.geoglam.org/index.php/en/countries-at-risk-en

http://asia-rice.org/index.php

www.arc.agric.za/Pages/Home.aspx

https://ipad.fas.usda.gov/cropexplorer/

http://edo.jrc.ec.europa.eu/edov2/php/index.php?id=1000

Drought Monitoring Systems

Global Drought Information System

www.drought.gov/gdm/

Global Integrated Drought Monitoring and Prediction System (GIDMaPS)

African Flood and Drought Monitor

http://drought.eng.uci.edu/

https://platform.princetonclimate.com/PCA_Platform/

https://climateserv.servirglobal.net/

NASA SERVIR ClimateSERV

http://climateengine.org/

Climate Engine

http://vam.wfp.org/sites/seasonal_monitor/

World Food Programme Seasonal Monitor

IGAD Climate Prediction and Application Center www.igad.org/

SADC Climate Services Center

www.sadc.int/sadc-secretariat/services-centres/climate -services-centre/

Centre Régional AGRHYMET

TABLE 3. FEWS NET overview references and resources and main monitoring and modeling portals.

\section{Overview References and Resources}

Climate science and famine early warning

Famine Early Warning Systems and Remote Sensing Dato

Real-Time Decision Support Systems: The Famine Early

Warning System Network

Agroclimatology overview

Scenario development

How climate forecasts strengthen food security

Monitoring/Modeling References and Resources

USGS FEWS NET data portal

Climate assessment resources

NOAA's African Desk: Twenty Years of Developing

Capacity in Weather and Climate Forecasting in Africa

A land data assimilation system for sub-Saharan Africa

food and water security applications

Crop Monitor for Early Warning
Verdin et al. (2005)

Brown (2008)

Funk and Verdin (2009)

http://fews.net/agroclimatology

http://fews.net/our-work/our-work/scenario-development

https://fews.net/sites/default/files/documents/reports

/Guidance_Document_Scenario_Development_2018.pdf

https://fews.net/sites/default/files/documents/reports

/Guidance_Document_Rainfall_2018.pdf

https://earlywarning.usgs.gov/fews/climate-workshop

Magadzire et al. (2017)

https://earlywarning.usgs.gov/fews

www.esrl.noaa.gov/psd/repository/alias/facts/

Thiaw and Kumar (2015)

www.cpc.ncep.noaa.gov/products/international/africa/africa.shtml

McNally et al. (2017)

https://ldas.gsfc.nasa.gov/fldas/

www.geoglam.org/index.php/en/countries-at-risk-en 

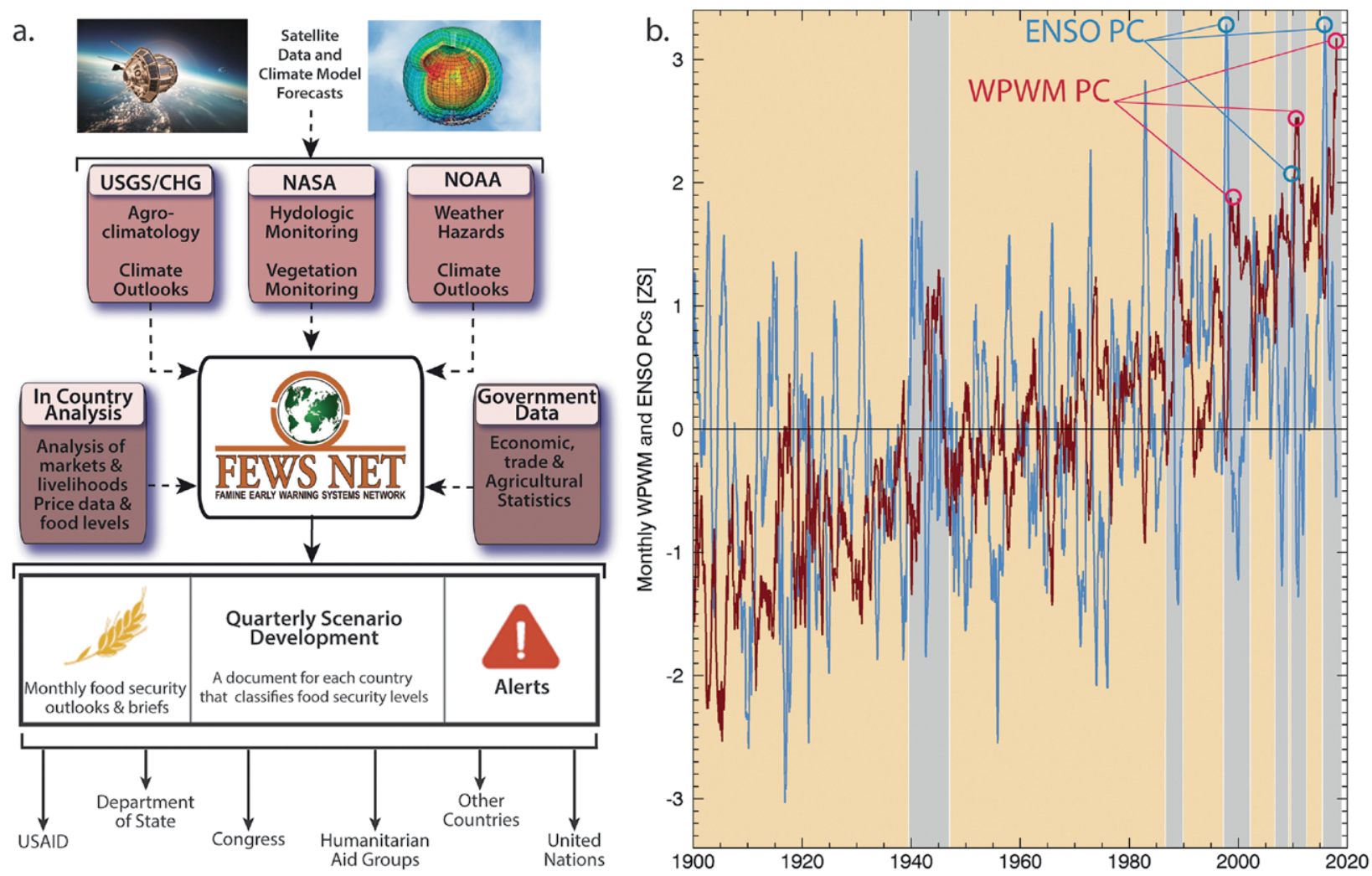

FIG. I. (a) Famine Early Warning Systems diagram. (b) Monthly standardized ENSO and WPWM principal components, based on a 1900-2017 baseline.

agroclimatology - a combined overview of climatic, hydrologic, and vegetative conditions. Since the livelihoods of food-insecure populations are often climate sensitive (Davenport et al. 2017, 2018), climate services and applied climate science form an important component of FEWS NET. In short, they complement the close monitoring and analysis of markets and prices, nutrition and disease, livelihoods, government policies, and conflict (Magadzire et al. 2017).

Like the U.S. Drought Monitor (Svoboda et al. 2002), FEWS NET also relies on objective drought indicators and expert judgment as input for food insecurity scenarios. The process of generating food insecurity outlooks includes regular and frequent consultations with the regional analysts to examine potential drought conditions. Where FEWS NET differs from most DEWS is in its specific focus on food insecurity. This focus, along with a 33-yr-long opportunity to refine its monitoring approach, has allowed FEWS NET to develop an effective system for food security-related drought early warning that "supports humanitarian-response programming while helping to reveal the root causes of food insecurity around the world" (Magadzire et al. 2017).

The timely and spatially focused alerts and outlooks provided by FEWS NET help FFP and partner agencies (Fig. 1a) guide effective humanitarian assistance, helping to save lives and secure livelihoods among some of the world's most food-insecure populations. A key source of the FEWS NET DEWS' strength is its ability to draw from a broad network of scientists in many agencies and areas of expertise (Table 3). FEWS NET relies heavily on regional scientists in sub-Saharan Africa, Central America, U.S. government institutions [National Aeronautics and Space Administration (NASA), National Oceanic and Atmospheric Administration (NOAA), U.S. Geological Survey (USGS), and the U.S. Department of Agriculture (USDA)], and the Climate Hazards Center (CHC) at the University of California, Santa Barbara. Other contributors include the University of Maryland-led HARVEST program and the NASA/ USAID SERVIR program. Additionally, FEWS NET works closely with African and European partner agencies (Tables 1 and 2). Below, we briefly describe FEWS NET's interagency strategy for supporting FEWS NET's Food Security Outlook (FSO) process. The efficacy of the FSO process relies on extensive analyses carried out before a growing season begins, in addition to detailed monitoring as the season commences. 


\section{CONTEXT: INCREASING CLIMATE VOLATILITY CONTRIBUTES TO INCREASING FOOD INSECURITY}

Exceptionally warm SSTs can prounderstanding and tracking these anomalies can support effective prediction. Recent FEWS NET research (Funk et al. 20l8d), for example, has highlighted the important role that extremely warm Pacific SST played in driving a sequence of droughts that began in Ethiopia in 2015, extended to southern Africa in 2015/16 and ended with back-to-back-droughts in equatorial East Africa in October-December and March-May of 2016/17. When considered collectively, this sequence of droughts helped push more than 29 million people into extreme food insecurity. The interaction of climate change and the EI Niño-Southern Oscillation (ENSO) may connect the dots between these crises (Funk et al. 2018d) while also providing opportunities for prediction, as extreme positive SST anomalies persist for many months.

$\mathrm{A} \sim+0.7^{\circ} \mathrm{C}$ anthropogenic enhancement of Niño-3.4 SSTs is thought to have substantially enhanced the intensity of drought over Ethiopia in 2015, and then southern Africa in 20I5/16 (Funk et al. 2016, 2018b), with these droughts pushing some $1 \mathrm{II}$ and 16 million Ethiopian and southern Africans, respectively, into extreme food crises. Figure Ib shows one metric of ENSO intensity, the first principal component (PC) of tropical Pacific SST (Funk and Hoell 20I5, 20I7). Examining this time series (blue line) we see that extreme (greater than +2 standardized anomalies) El Niño events have appeared frequently over the past 20 years (in 1997/98, 2008/09, and 2015/16). Observations and SST-driven atmospheric simulations, as well as climate change simulations, suggest that these more frequent, more extreme El Niños have greater drought-producing potential than, perhaps, initially expected (Funk et al. 2016, 2018b,d; Hoell et al. 2015; Pomposi et al. 2018). These events, however, are well predicted by our current generation of climate models (Tippett et al. 2017), creating opportunities for effective early warning.

Following these El Niño events, we often see a warming of the global oceans and the west Pacific, in particular, with the latter accompanying La Niña-like climate responses.

The intensity of such warming can be quantified via the West Pacific Warming Mode (WPWM) - the first PC of global SSTs after the influence of ENSO is removed (Funk and Hoell 2015, 2017). After 1997/98, 2009/10, and 2015/16 El Niño events, we see lagged increases in the WPWM and below-normal rainfall in East Africa, associated with persistent warm west Pacific SST. Observations and SSTdriven atmospheric simulations, as well as climate change simulations, suggest that these warm SSTs have improved drought-producing potential for East Africa (Funk et al. 2018d, 2019). Thus, climate change and ENSO-related climate extremes (Fig. Ib) may create multiyear sequences of enhanced climate volatility: first producing El Niño-related droughts in northern Ethiopia and southern Africa, then producing droughts over eastern equatorial Africa. Managing these climate risks will require effective FSOs.
FEWS NET FOOD SECURITY OUTLOOK. FSOs enable humanitarian agencies to anticipate and target aid. Every month, FEWS NET updates its 8-month FSOs through a rigorous, structured scenario-development process (Magadzire et al. 2017). FSOs are derived using a three-part process in which 1) analysts draft preliminary agroclimatology assumptions; 2) the draft analyses are reviewed and modified by climate scientists in light of available scientific evidence; and 3) the reviewed assumptions are presented back to food security analysts, who use them to help develop quantitative, evidence-based food security outlooks and briefs, quarterly food security scenarios for each country, and alerts (Fig. 1a). Initially, analysts draft assumptions about how agroclimatology will likely impact future food security. These assumptions are region-specific, focusing on the most vulnerable and high-risk areas and covering all FEWS NET countries. FEWS NET utilizes multiple lines of evidence for building agroclimatological assumptions. This approach combines prediction (e.g., "ocean temperatures appear conducive to drought in this food-insecure region") with monitoring (e.g., "conditions to date have reduced soil moisture and vegetation health"), and detailed field assessments (e.g., "crop models and field assessments indicate a failed harvest; millions of people are likely to face a food crisis").

The process works as follows: when an agroclimatology assumption is required for a time period during which no other information is available-for example, 6-8 months ahead-assumptions are made based on historical climatology (e.g., typical variability and trends in rainfall or temperature). For shorter lead times, climate modes such as the El NiñoSouthern Oscillation (ENSO) and long-range climate forecasts are used to derive assumptions. Finally, with the onset of the rainfall season, seasonal monitoring data are progressively incorporated into the analysis.

Translating early warning into action. While a full discussion of humanitarian responses is beyond the scope of this study, we briefly contrast responses and resilience between the 2011 and 2017 East African food security crises, drawing on a resilience analysis recently carried 
a.
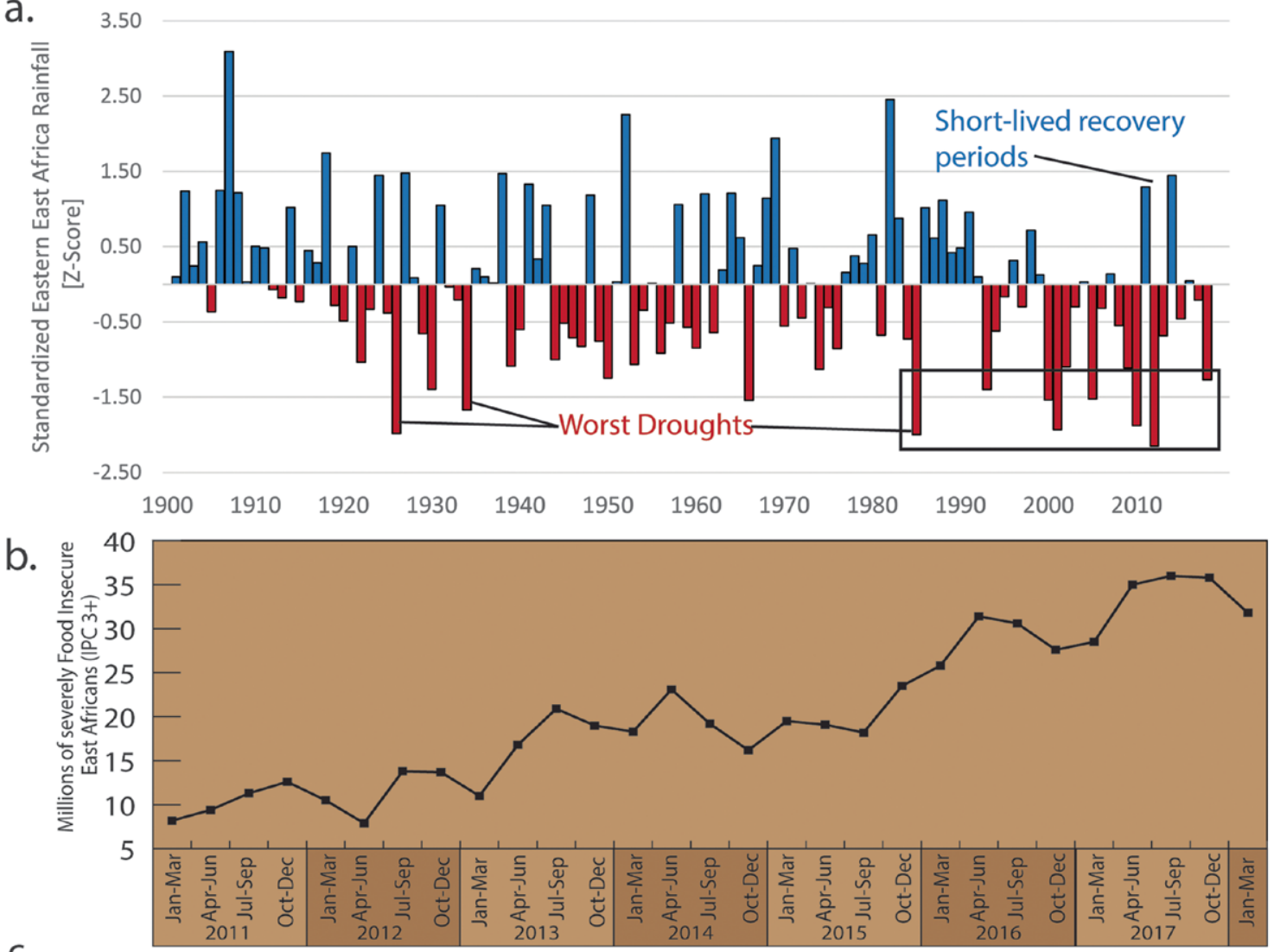

C.

\begin{tabular}{|l|l|l|l|}
\hline Stages of Drought Monitoring Progression & \multicolumn{1}{|c|}{ Example } & Drought Alert Level \\
\hline At Onset: Link to large scale climate & $\begin{array}{l}\text { Rainfall and crop model } \\
\text { trends indicate increasing } \\
\text { drought in Eastern Ethiopia }\end{array}$ & Sild Concern \\
\hline bring reduced rains to \\
Ethiopia
\end{tabular}

FIG. 2. (a) 1900-2017 Mar-May standardized precipitation index (SPI) time series for eastern East Africa. (b) 20II-18 FEWS NET/East African Food and Nutrition Working Group food-insecure population estimates. (c) Stages of a canonical drought monitoring progression. 

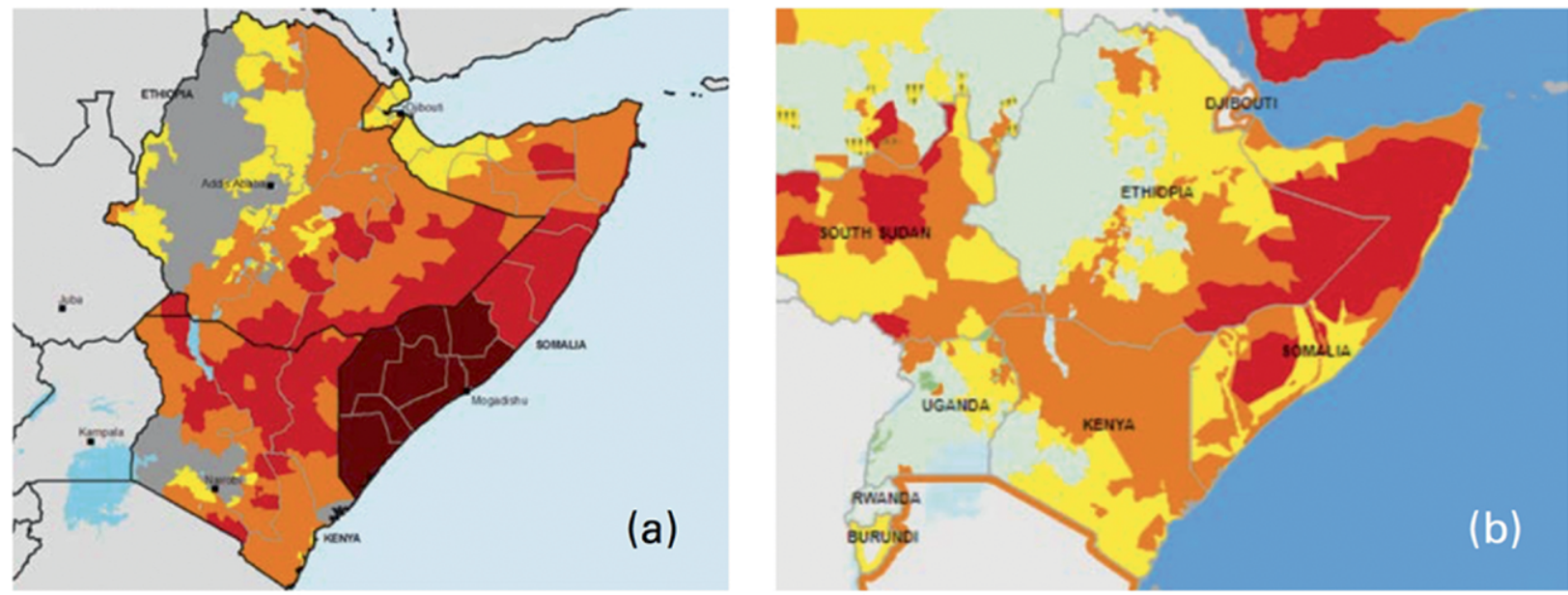

\section{Minimal}

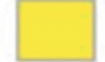

2. Stressed

\section{Fig. 3. Integrated Food Insecurity Phase Classification Jul-Sep 201 I and (b) Jun-Sep 2017.}

out for USAID (Funk et al. 2018d). East Africa has experienced substantial declines in March-May rains (Fig. 2a) and substantial increases in food insecurity (Fig. 2b). The 2011 March-May drought over the eastern Horn of Africa was one of the worst droughts on record (Fig. 2a). It severely impacted Somalia, Ethiopia, and Kenya (Fig. 3a). Using an analysis of the ENSO climate mode, available long-range climate forecasts, and an interpretation drawing on local knowledge and prevailing food security conditions, FEWS NET was able to issue a food security early warning report by August 2010 (Funk 2011). Unfortunately, conflict obstructed an effective response, resulting in over 250,000 human deaths in Somalia (Checchi and Robinson 2013; Hillbruner and Moloney 2012). Over 12 million people in East Africa required urgent humanitarian assistance. The severe, prolonged drought had adverse socioeconomic, environmental, and political impacts in the worst-affected regions of the eastern Horn and, more specifically, in Somalia, Kenya, and Ethiopia. Overall, $\$ 1.7$ billion (U.S. dollars) was provided to alleviate this human catastrophe, representing $71 \%$ of the United Nations' appeal for $\$ 2.4$ billion (U.S. dollars) in early 2011.

More recently, FEWS NET predicted the unprecedented severe 2016/17 drought, which resulted in about 27 million people (June 2017) requiring urgent food assistance (Fig. 3b). It also led to a United Nations' appeal for $\$ 4.4$ billion (U.S. dollars) in funding - twice the 2010/11 appeal. The 2016/17 drought was relatively more widespread than the 2010/11 drought, extending from the eastern Horn into the western sector of the region. The drought adversely affected main staple food-production zones of Kenya, Uganda, and Tanzania.

Between 2010 and 2016, FEWS NET scientists developed many new monitoring tools and performed diagnostic analyses to enhance our understanding of the mechanisms driving East African droughts and food insecurity; these developments are briefly discussed below and detailed in the more than 100 published papers listed in the supplemental bibliography (https://doi.org//0.II75/BAMS-D-17-0233.2). The FEWS NET FSO process and links with international partners (Table 1) were both developed more fully. These advancements aided in the predictions of the 2016 October-December and 2017 March-June East African droughts in October and December of 2016, followed by detailed and ongoing monitoring of the associated impacts on crop and pasture conditions. This information helped motivate large and sophisticated humanitarian responses mitigating the ensuing severe food shortages. For example, the 2017 FFP response for Somalia ${ }^{3}$ totaled $\$ 240$ million (U.S. dollars) and involved the disbursement of 58 million metric tons of humanitarian aid. This assistance came in the form of therapeutic ready-to-use foods for the treatment of severe malnutrition and in-kind food aid transfers, as well as cash and market-based interventions such as cash transfers for food, cash-for-work activities, and food vouchers. Expectations of poor

${ }^{3}$ https://reliefweb.int/report/somalia/somalia-food-assistance-fact-sheet-september-2I-20I7 
crop and pasture outcomes for the 2017 March-May rainy season helped motivate preemptive food aid arrivals in early 2017. When the March-May rains failed, on-the-ground assistance helped prevent the runaway food price increases, food access crisis, and increased mortality experienced in 2011. Five years of extensive research (see supplemental bibliography) and investments in improved monitoring, modeling, and interagency collaboration (Table 3) provided substantially improved advance warning that helped prevent a repetition of the 2011 Somali famine.

In Kenya, the FFP response totaled $\$ 79$ million (U.S. dollars) and involved 56 million metric tons of assistance. ${ }^{4}$ FFP partnered with the World Food Programme to provide money or food in exchange for work community assets such as local irrigation systems and roads. FFP also provided the United Nations Children's Fund ready-to-use therapeutic foods to treat severe malnutrition in droughtimpacted arid districts. FFP further provided supplementary nutritious foods for all children under the age of 5 and pregnant and lactating women in the Kenyan counties with the highest levels of acute malnutrition.

At the request of USAID, the CHC examined Kenya's resilience to the 2010/11 and 2016/17 droughts (Funk et al. 2018c). The results of this study suggest that "despite repeated severe droughts in 2016/17, the severity of Kenyan food insecurity was substantially less than during the 2010/11 drought and substantially less than might be expected given historical relationships between drought severity and humanitarian need. In line with this, U.S. government expenditures were also substantially less (about half) than what might be expected based on historical relationships" (Funk et al. 2018c). The evaluation of Kenya's resilience identified the following key findings supporting these conclusions (Funk et al. 2018c):

1) Both the extent and depth of food insecurity was much smaller in 2017 than in 2011. In 2011 the number of severely hungry Kenyans was $\sim 2.8$ million, and in 2017 it was $\sim 1.75$ million.

2) Based on the historical relationship between drought severity and humanitarian assistance, an estimated 500,000 fewer people were in need of humanitarian assistance in 2017 than would be expected.

3) Despite three severe consecutive droughts, deflated U.S. government food aid expenditures for Kenya in 2017 were about half (51\% and 40\%) of the expenditures during the last two severe crises in 2011 and 2009.
4) Despite a more severe agricultural shock, maize prices normalized more quickly in 2017 than 2011; however, this may reflect market interventions by the Kenyan government.

The improved early warning systems and multiagency responses employed during the 2016/17 East African drought sequence contributed to greater Kenyan resilience and lower mortality rates in Somalia in comparison with the 2010/11 drought. It should be noted that many DEWS (Table 2), not just FEWS NET, provided the effective and convergent early warning of climate hazards; working together, these agencies helped create an effective alarm. An especially important role was played by East African meteorological and drought risk management agencies, and regional institutions like the Intergovernmental Authority on Development (IGAD) Climate Prediction and Applications Centre (ICPAC; www.icpac.net), the Regional Centre for Mapping and Resource Development (RCMRD; www.rcmrd.org), and the IGAD Food Security and Nutrition Working Group (FSNWG). It should also be noted that drought early warning is just one small component of effective famine mitigation. Nevertheless, substantial progress has been made within the FEWS NET DEWS between 2010 and 2018, as measured by the number of publications produced, approximately 100 since 2011 (supplemental bibliography), the substantial improvements in the FEWS NET DEWS data portals ${ }^{5}$ (Table 3), an enhanced monthly FSO process (Magadzire et al. 2017), numerous capacity-building efforts and partnerships in Africa and Central America, and effective links to the NASA/USAID SERVIR and HARVEST programs. In terms of datasets, the FEWS NET DEWS is now supported by the FEWS NET Land Data Assimilation System (FLDAS; McNally et al. 2017) version 2 of African Rainfall Climatology (ARC2; Novella and Thiaw 2013) and Seasonal Rainfall Performance Probability (SPP) analyses (Novella and Thiaw 2016), actual evapotranspiration estimates (Senay et al. 2011, 2013), the CHC Infrared Precipitation with Stations data (CHIRPS; Funk et al. 2015b), and Centennial Trends (Funk et al. 2015a) precipitation archives. Each insight, monitoring tool, and dataset provides value, and FEWS NET applies

\footnotetext{
${ }^{4}$ https://reliefweb.int/report/kenya/kenya-food-assistance -fact-sheet-september-I-2017

${ }^{5}$ https://earlywarning.usgs.gov/fews, www.cpc.noaa.gov /products/international/africa/africa.shtml, https://lis.gsfc .nasa.gov/projects/fewsnet, http://chg.ucsb.edu
} 
them in a structured way before and during severe droughts.

Next, we provide a detailed example of the multistage early warning process in the context of a real-world scenario using an example from the 2015 drought in Ethiopia.

FSO: AN EXAMPLE OF MULTISTAGE EARLY WARNING IN ETHIOPIA IN 20I5. Figure 2c provides a schematic diagram of an effective early warning progression. We examine how this progression can work in a real-world scenario like the El Niño-related 2015 drought event in Ethiopia. In the left column, we list potential information sources applicable to each stage of the progression. In the center column, we list specifics pertinent to Ethiopia. On the right, we denote increasing levels of concern. As we progress through the season, our certainty and spatial specificity increase.

Before the season begins, we know that Ethiopia is very food insecure, has a rapidly growing population, and has experienced an increased frequency of drought in the eastern parts of the country. In May 2015, we see Niño-3.4 sea surface temperature (SST) anomalies rise above $+1^{\circ} \mathrm{C}$. We know that prior research has identified robust negative teleconnections associated with El Niños and that the February-May Belg season has been poor in many places. Then, looking forward by one month, we use the FLDAS (McNally et al. 2017), in conjunction with satellite precipitation fields, to produce and examine midseason soil moisture anomalies. Such maps will have identified some exceptionally dry conditions. NASA scientists then run their hydrologic models out to the end of the season using historical data, thus producing useful predictions. Use of the crop water requirement satisfaction index (WRSI) model provides a similar midseason snapshot of water availability and forecasts of end-of-season crop performance. While still an active area of research, FEWS NET is working toward combining midseason remote sensing data with forecast-based outlooks derived from weather and climate models. To this end, we have developed CHIRPS-compatible downscaled daily precipitation fields based on weather forecasts from the Global Ensemble Forecast System. ${ }^{6}$

Within a season, FEWS NET depends heavily on a convergence-of-evidence approach that draws on many information sources (Brown 2008). All sources of information contain some level of uncertainty. Translating satellite-observed radiance information into accurate assessments of climatic shocks is difficult. FEWS NET, therefore, looks at multiple types and sources of remotely sensed information such as precipitation estimates, normalized difference vegetation index (NDVI) imagery, ${ }^{7}$ and satellite estimates of actual evapotranspiration (Senay et al. 2007, 2011, 2013). In addition to satellite information, on-theground reporting and station observations provide critical input to midseason assessments.

Finally, as the season draws to a close, FEWS NET early warning scientists work to refine their assessments and consider questions such as the following. How bad might "bad" be? Is it the worst drought in 10,20 , or 50 years? Can we use WRSI or statistical relationships to quantify the likely crop production loss? Can we use FLDAS runoff to quantify deficit in per capita water availability? At the close of the growing season, high-resolution vegetation imagery provides an excellent source of spatially detailed information related to crop production and pasture conditions.

The next several sections expand on FEWS NET activities at each of these progressive drought early warning stages. Effectively working in unison, early warning products provided at each successive time period can provide increasingly accurate, specific, and actionable information. Below, we describe some of the major components of the FSO that are led by FEWS NET partners.

Before the SEASON: Using historical INFORMATION to GUIDE EARLY WARNING. Before a season begins, FEWS NET partners use historical information to guide early warning in three ways: 1) contextualizing current agroclimatic conditions using long-term datasets (e.g., precipitation datasets), 2) investigating climate attributes of the past drought events using historical climate model simulations, and 3) mapping food insecurity "hot spots."

USING SATELLITE-GAUGE PRECIPITATION TO MONITOR CURRENT AGROCLIMATIC CONDITIONS. The lack of reliable data in many developing countries makes effective early warnings challenging. FEWS NET scientists use blended satellite-rain gauge rainfall estimates such as the CHIRPS dataset (Funk et al. 2015b) and the Climate Prediction Center's ARC2 (Novella and Thiaw 2013) to identify droughts. The NOAA Climate Prediction Center (CPC) combines real-time observations with historical ARC2 data to provide SPP analyses (Novella and Thiaw 2016). Such tools allow analysts to assess the probability of a midseason recovery.

\footnotetext{
${ }^{6}$ http://blog.CHC.ucsb.edu/?p=443

${ }^{7}$ https://earlywarning.usgs.gov/fews/product/448
} 
INVESTIGATING CLIMATE ATTRIBUTES OF PAST DROUGHT EVENTS. FEWS NET also uses observations, reanalyses, and atmospheric global circulation model simulations, such as those hosted at the NOAA Facility for Climate Assessments, ${ }^{8}$ to perform diagnostic analyses of recent drought events; to examine the influence of El Niños and La Niñas (Hoell et al. 2014, 2015; Pomposi et al. 2018), the North Atlantic Oscillation (Bekele-Biratu et al. 2018), the subtropical Indian Ocean dipole (Hoell et al. 2017a), and the West Pacific Warming Mode (WPWM; Funk and Hoell 2015); and to look for opportunities for prediction. FEWS NET has also routinely participated in the annual $B A M S$ "Explaining Extreme Events" climate attribution issues ${ }^{9}$ - examining the potential impacts of climate change on recent African drought events.

The ENSO mode characterizes the warmth of SSTs in the equatorial east Pacific. This mode obtains the highest values when a strong El Niño occurs, as in 2015/16. The WPWM characterizes the warmth of global SSTs after the influence of ENSO has been removed. This mode loads strongly on the western Pacific. When a strong El Niño event appears probable, we also are likely to experience drought in several FEWS NET regions such as Ethiopia, southern Africa, and Central America (Hoell et al. 2015; Korecha and Barnston 2007; Nicholson 1986; Ratnam et al. 2014; Reason et al. 2000). When the WPWM mode and west Pacific SST are exceptionally warm and a strong temperature gradient exists between the eastern and western Pacific, dry conditions are likely to prevail over East Africa (Funk et al. 2014; Hoell and Funk 2013, 2014; Lyon and DeWitt 2012; Shukla et al. 2014a,b).

FEWS NET science has also resolved the East African climate paradox (Rowell et al. 2015) by attributing the observed declines (Fig. 2a) to an interaction between anthropogenic warming in the western Pacific and natural ENSO climate variability (Funk et al. 2018d; Hoell et al. 2017b) that has increased the region's sensitivity to La Niñas (Hoell and Funk 2013; Hoell et al. 2014), creating opportunities for effective prediction (Funk et al. 2014; Shukla et al. 2014a,b). The "paradox" resides in the fact that climate change simulations anticipate a wetter East Africa, while FEWS NET research has identified substantial drying, especially during the March-May long rains. Climate change models may be overestimating the influence of El Niño-like warming in the east Pacific. The latest FEWS NET research (Funk et al. 2018d, 2019) indicates that exceptional increases in west Pacific SSTs following an El Niño often result in severe and predictable East African droughts.
MAPPING FOOD INSECURITY “HOT SPOTS.” Historical climate data (Funk et al. 2015a,c; Schneider et al. 2017) can also be used as part of FEWS NET's vulnerability identification process (Funk and Verdin 2009; Hoell and Funk 2013; Hoell et al. 2014). Such analyses first identified the decline (Fig. 2a) in East Africa's March-May rains (Funk et al. 2005; Verdin et al. 2005). While climate change models (Giannini et al. 2018) predict increased rainfall, the observations indicate a dramatic increase in the frequency of droughts with only a few good rainfall seasons since 1999, providing little chance for recovery. Concomitant with this drying has been a substantial increase in food insecurity since 2011, the year of the Somali famine (Fig. 2b). At the peak of the 2011 Somali famine, some 12.6 million people are thought to have experienced pre-famine conditions. In 2017, at the peak of a similar series of La Niña-induced droughts, almost 3 times as many East Africans faced severe food insecurity.

Even before a season begins, FEWS NET research allows us to identify where droughts are likely to occur and where droughts might produce the greatest food security impacts. Once the season commences, a powerful suite of satellite-based monitoring tools is used to track potential hazards.

DURING THE SEASON: WEEKLY AND MONTHLY AGROCLIMATIC MONITORING. During a growing season, three main monitoring activities contribute to FSOs: 1) Weekly Hazard Outlooks (CPC), 2) Crop Monitoring for Early Warning (University of Maryland's HARVEST $^{10}$ ), and 3) FEWS NET Land Data Assimilation System (NASA).

WeEkLy WEATHER haZARD OUTLOOKS. The preparation of weekly hazards outlooks in support of the FSO is led by the CPC, with contributions from other FEWS NET partners. The objectives and processes are described in detail in Thiaw and Kumar (2015). The hazards outlooks take into account the evolution of climate conditions over the past several weeks and months, as well as forecasts from short-range to subseasonal and seasonal time scales. These outlooks depict areas that have been consistently dry or exposed to flooding (or other conditions such as extreme heat or cold, and locust outbreaks) that

\footnotetext{
${ }^{8}$ www.esrl.noaa.gov/psd/repository/alias/facts

${ }^{9}$ www.ametsoc.org/ams/index.cfm/publications/bulletin -of-the-american-meteorological-society-bams/explaining -extreme-events-from-a-climate-perspective/

${ }^{10}$ https://nasaharvest.org/
} 


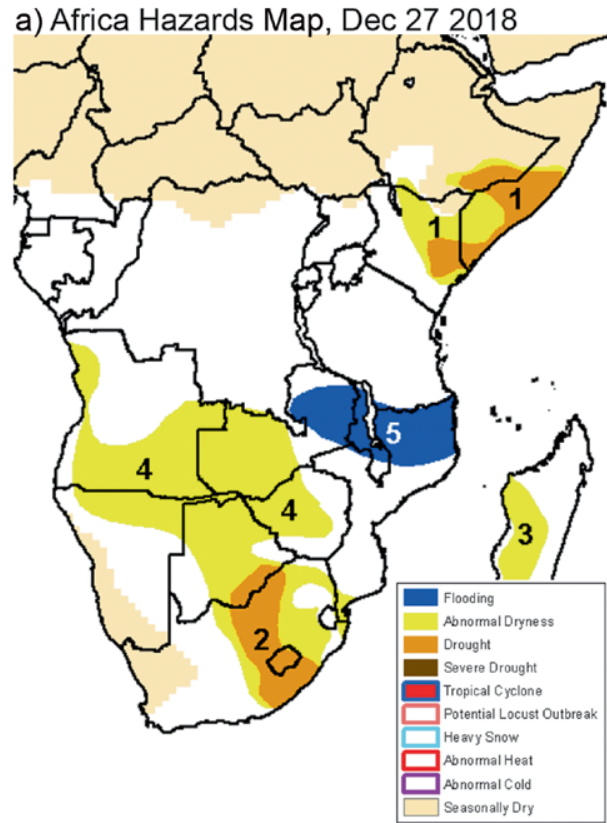

b) East Africa Crop Monitor December 2018

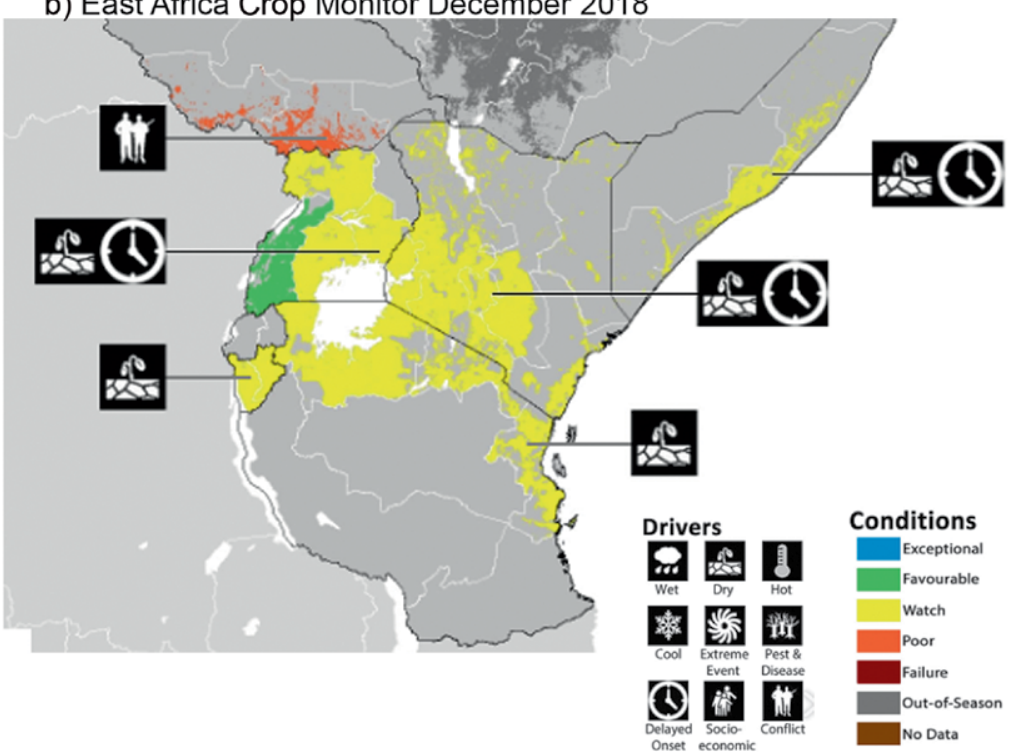

FIG. 4. (a) Africa weekly hazards outlook, valid 27 Dec 2018-2 Jan 2019. Weather and climate conditions with adverse impact on food security are depicted. (b) Africa and Yemen CM4EW, Dec 20I8. The CM4EW bulletin routinely reports on approximately 80 countries.

might result in adverse long-term impacts on crops and pastures, which could lead to food insecurity. The primary inputs to the hazards outlooks include rain gauge data and satellite rainfall estimates [Rainfall Estimation, version 2 (RFE2) and ARC2], rainfall and surface temperature forecasts up to 16 days, and subseasonal and seasonal climate forecasts. Other products considered include the USGS WRSI for crops and rangelands (Senay and Verdin 2003; Verdin and Klaver 2002), NDVI (J. F. Brown et al. 2015), NOAA's vegetation health index (VHI; Kogan 2002), and field observations. With knowledge of current conditions and forecasts, areas at risk of weather hazards and potential food insecurity are identified and mapped. A sample hazard outlook, valid for 27 December 2018 to 2 January 2019, is shown for Africa in Fig. 4a. Polygon shapes show areas of concern for flooding or drought, and numbering the polygons allows for continued monitoring of the same areas. Color shades determine the nature and severity of the hazards. The sample outlook (Fig. 4a) identifies droughts with dark tan shades. Polygon 1 in eastern Kenya and portions of southern Somalia features drought associated with an early cessation of rain with a negative impact on ground conditions. When the outlook was released, rainfall recovery was very unlikely, given that the October-December rainfall season was drawing to an end. Polygon 2 in the Republic of South Africa also identifies a very poor start to the maize growing region across one of the most productive regions in sub-Saharan Africa. Polygons 3 and 4 (yellow) highlight areas of developing dryness that could have adverse impacts on crops. In contrast, polygon 5 (dark blue) features potential flooding associated with extremely heavy rainfall across Malawi and parts of neighboring countries. The hazards outlooks serve as one component of the food security outlooks process and are integrated with many other factors to predict areas at risk for food insecurity.

The hazard outlooks are supported through the development of interactive monitoring tools that allow food security analysts to evaluate several remotely sensed datasets and to place the information in the context of historical norms through the generation of both maps and time series data at multiple spatial scales. An example of one such tool is the USGS Early Warning eXplorer (EWX), which provides access to image data for rainfall, NDVI, land surface temperature, snow depth, and snow water equivalent (SWE). Depending on product type, other available imagery includes anomalies, $z$ score, and percent of median. The $\mathrm{EWX}^{11}$ provides a variety of temporal scales from daily to 3 -month accumulations. Time series tools allow the user to summarize a particular variable across administrative levels, crop growing areas, or drainage basins.

\footnotetext{
${ }^{11}$ https://earlywarning.usgs.gov/fews/ewx/index.html
} 
a

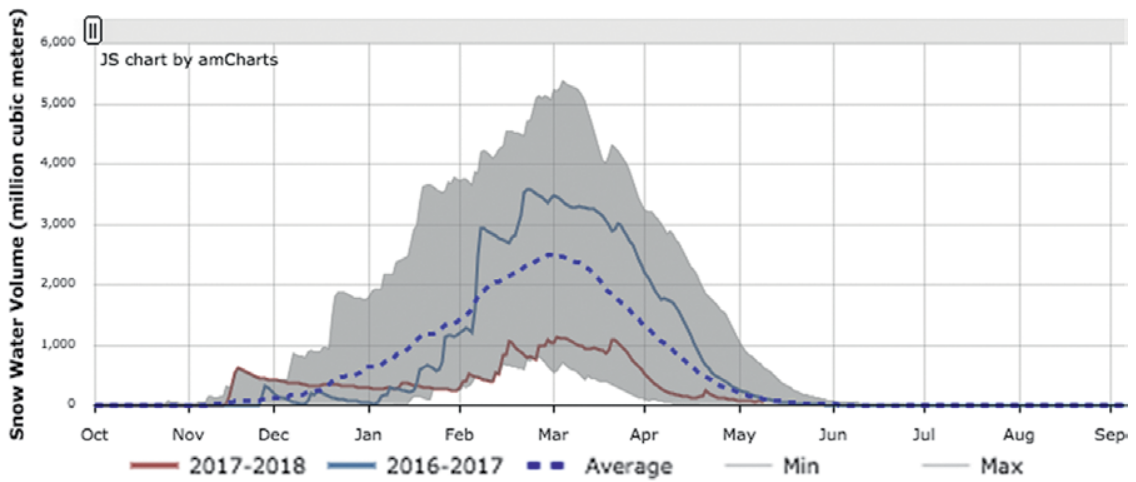

b

\section{Change in Water Stress} March 2018 (Final)

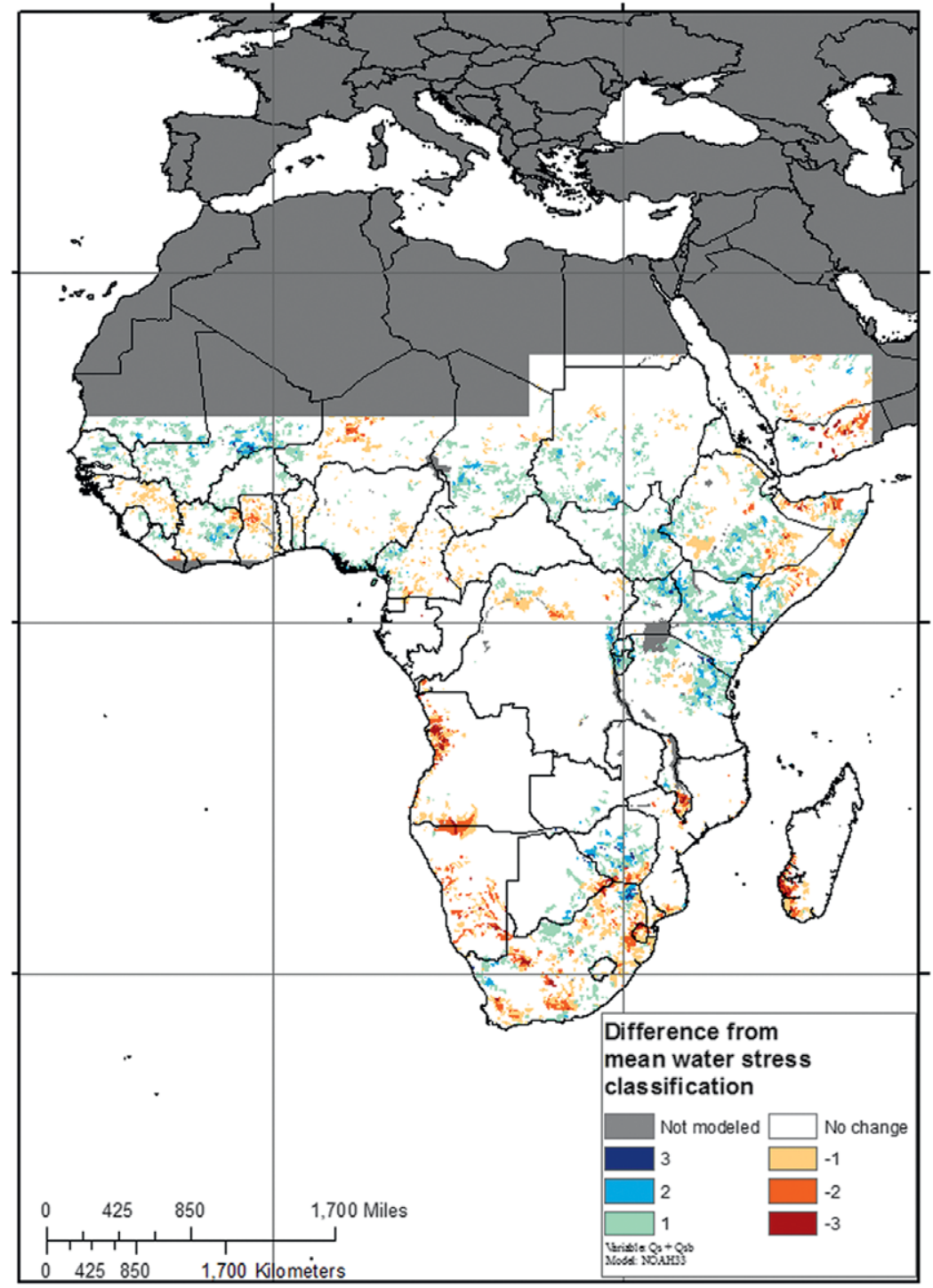

FIG. 5. (a) Afghanistan snow water equivalent time series for the Helmand basin for 2016/17 and 2017/18. Also shown are the historic maxima, minima, and average. Central Asia and Afghanistan snow modeling are available at I-km resolution, daily from 200 I to present from the USGS, Earth Resources Observation and Science Center FEWS NET website. (b) Falkenmark water stress anomalies for Mar-May 2018.
CROP MONITORING FOR EARLY WARNING. The Crop Monitor for Early Warning (CM4EW) is a multiagency effort to assess crop growing conditions for countries at risk of food insecurity. The CM4EW addresses the Countries-atRisk component of the G20 Group on Earth Observations Global Agricultural Monitoring (GEOGLAM) initiative (Fig. 4b). The CM4EW (cropmonitor.org) is a monthly collaborative activity that involves multiple international, national, and regional institutions that provide crop condition assessments based on a range of satellite-derived crop condition indicators alongside ground information and analyst expertise. Classifications are accompanied by associated drivers such as dryness, delayed planting, or conflict, among others. Each month, entries are made into the Crop Monitor interface by crop analysts representing the various participating agencies. Crop condition discrepancies are then vetted and discussed on a monthly teleconference until a consensus among analysts is reached. This vetting process has helped to substantially reduce uncertainty in crop condition assessments. It also reflects the first time that the international community concerned with monitoring food production in these vulnerable food-insecure countries has come together on a monthly basis to conduct joint assessments. These monitoring activities contribute to the decision support provided by FEWS NET. 
feWS net Land Data Assimilation System. The FEWS NET Land Data Assimilation System allows for the routine monitoring of hydrologic variables beyond precipitation such as snow, soil moisture, and water stress. While there have been a number of prototypes for global drought monitoring systems (Nijssen et al. 2014; Pozzi et al. 2013), as well as routinely updated hydrologic modeling systems for regional drought (e.g., Sheffield et al. 2014; Svoboda et al. 2002) and global flood monitoring (Wu et al. 2014), the goal of the FLDAS is to provide a land data assimilation system specifically for the domains, data streams, and monitoring and forecast requirements associated with the FEWS NET FSOs. The FLDAS is a custom instance of the NASA Land Information System (LIS) (Kumar et al. 2006) adapted to work with the data and models commonly used by FEWS NET. Adopting LIS has allowed FEWS NET to leverage existing land surface models such as Noah (Ek et al. 2003) and the Variable Infiltration Capacity (VIC; Liang et al. 1994) models to address the needs of the food security community. FLDAS evaluation, including comparisons with NDVI, remotely sensed evapotranspiration estimates, microwave soil moisture, and streamflow observations can be found in McNally et al. (2016, 2017) and Jung et al. (2017). Additional studies have explored the relationship between FLDAS outputs and crop yields (Agutu et al. 2017; McNally et al. 2015).

FLDAS is updated daily, bimonthly, and monthly, depending on availability of rainfall inputs. This schedule allows FLDAS to provide information both during and after different growing seasons. FLDAS can address questions like, "How do current snowpack levels in Afghanistan compare with the last 18 years?" or "Based on model runs using CHIRPS inputs, how does current water stress compare to the last 33 years?"

An example of FLDAS for Afghanistan SWE output for February 2018 is displayed in Fig. 5a. The model produces estimates of SWE using NOAA's near-real-time meteorological inputs (Derber et al. 1991) and the Noah version 3.6 land surface model. These estimates are delivered to the USGS, where maps, time series, and interactive tools are updated. This allows analysts to make a comparison between the current conditions of the SWE and its historical record (2001 to present). During the winter of 2017/18, Afghanistan experienced extremely low snow levels. Figure 5a shows the seasonal progression of SWE values for a major basin (the Helmand) during a typical year (2016/17) and the very low 2017/18 season. Also shown are historical minimum, maximum, and average SWE values. Since Afghanistan depends on snowmelt to support irrigated agriculture, monitoring SWE values provided valuable advance notice of future food shocks. The FLDAS soil moisture and runoff have also been used to illustrate the severity and extent of several major drought events in Africa, including the 2015 Ethiopia drought, ${ }^{12} 2015 / 16$ southern Africa drought, ${ }^{13}$ and the 2016 eastern Horn of Africa drought. ${ }^{14}$

In addition to the use of FLDAS to contextualize hydrologic conditions, new efforts are tracking per capita water availability to highlight locations where both supply (runoff) and demand (population density) may be contributing to water scarcity or flood-risk outcomes. Per capita water stress can be estimated using the Falkenmark Index (Falkenmark 1989). Figure 5b shows March-May 2018 water stress anomalies. This panel reflects the above-normal rainfall that much of East Africa experienced in 2018, resulting in catastrophic flooding in Kenya and the Juba-Shabelle basin in Somalia. ${ }^{15}$

Both of these examples demonstrate how FEWS NET can move beyond relative conditions (rainfall anomalies) to more accurately quantify water availability - be it for crops, pastures, or people-and assess how this volume of water compares to recommended thresholds (e.g., the Falkenmark Index). Other benefits of the FLDAS include the ability to partition readily available satellite rainfall estimates and meteorological reanalysis into different variables in the energy and water budget, allowing for comparisons of these rainfall-driven estimates with independent remote sensing observations of, for example, thermal-based evapotranspiration, microwavederived soil moisture, and terrestrial water storage from the Gravity Recovery and Climate Experiment (GRACE) mission (Tapley et al. 2004). Research and development within this modeling framework will soon allow FLDAS to augment its capabilities to include dynamic seasonal and weather forecasts to make predictions of hydrologic conditions. These improvements and additional case studies demonstrating FLDAS utility will further improve analysts' abilities to use these data and answer questions regarding water availability and its impact on food security outcomes.

\footnotetext{
12 http://fews.net/east-africa/ethiopia/special-report /december-I7-20I5

${ }^{13}$ www.fews.net/southern-africa/special-report/march-2016 ${ }^{14}$ http://fews.net/sites/default/files/documents/reports /FEWS\%20NET_Horn\%20 of\%20Africa\%202016\%20 Drought\%20Map\%20Book.pdf

${ }^{15}$ https://reliefweb.int/disaster/ff-20l8-000030-ken
} 
CONCLUSIONS. Drought early warning science, in support of famine prevention, is a rapidly advancing field that is helping to save lives and secure livelihoods. With over 33 years of continuous development, the Famine Early Warning Systems Network (FEWS NET) provides a compelling example of science in action, connecting a well-developed Drought Early Warning System (DEWS) with food security analysts to help motivate and target effective humanitarian responses (Fig. 1a). The unique multiagency structure of the FEWS NET DEWS connects scientists in food-insecure countries with colleagues in the USGS, CHC, NOAA, NASA, USDA, and the University of Maryland-led HARVEST program. The breadth of this network supports analyses that range from short-term hazards alerts, to seasonal monitoring and prediction reports, to long-term evaluations of changes in climate and the determinants of food insecurity and resilience. Here, we have described some of the climate and hydrologic science behind FEWS NET with reference to recent early warning applications. We have summarized the FEWS NET Food Security Outlook (FSO) process and the major activities led by FEWS NET partners that contribute to the FSO. We have also described how new FEWS NET research suggests that global warming may be intensifying tropical climate extremes. These extremes may provide opportunities for early warning, and we have provided examples demonstrating effective forecast and monitoring applications associated with the recent 2015/16 extreme El Niño and subsequent 2016/17 La Niña. While more work needs to be done to leverage the best new climate, satellite, and agrohydrometeorological modeling resources, FEWS NET is helping developing nations anticipate, monitor, and cope with the impacts of severe droughts. As discussed above, Kenya's improved responses during the 2016/17 crisis helped reduce the impact of backto-back severe droughts. Regional and national agencies, ICPAC, RCMRD, the FSNWG, and Kenya's Meteorological Department (www.meteo.go.ke/) and National Drought Management Authority (NDMA; www.ndma.go.ke/) have made great improvements in their monitoring, prediction, and disaster risk reduction activities. Like FEWS NET, these agencies effectively anticipated and monitored the 2016/17 droughts, helping to trigger Kenya's own substantial drought intervention activities. Going forward, innovations such as weather index insurance and Kenya's National Drought Management Authority Drought Contingency Fund may further enhance the capacity of fragile food economies to absorb the impacts of twenty-first-century droughts.
ACKNOWLEDGMENTS. Contributors from the National Aeronautics and Space Administration (NASA) Goddard Space Flight Center (GSFC) acknowledge the financial support from the NASA Earth Science Applications: Water Resources program Award 13-WATER13-0010. Computing was supported by the resources at the NASA Center for Climate Simulation (NCCS). Initial support was provided by NASA Research Opportunities in Space and Earth Science (ROSES) Decisions-08-0070 “A Land Data Assimilation System for Famine Early Warning," continued support provided by FEWS NET's Participating Agency Program Agreement Water Availability Monitoring Activity. This work was supported by U.S. Geological Survey (USGS) Cooperative Agreement G14AC00042 and NASA Grants NNX16AM02G and NNX15AL46G. USGS efforts were supported by a Participating Agency Program Agreement with USAID/FFP and the USGS Drivers of Drought program. Special thanks to Kristine Verdin for FLDAS support and figures, and Logan Karsten and Greg Fall at the National Oceanic and Atmospheric Administration (NOAA) National Operational Hydrologic Remote Sensing Center (NOHRSC) for providing version 1 of the Central Asia snow modeling work. We would also like to thank Juliet Way-Henthorne, the Climate Hazards Center's Technical Editor and Writer, for providing copious editorial suggestions and improvements. Sandra Cooper, Bureau Approving Official of the USGS Office of Science Quality and Integrity, also provided valuable suggestions improving the quality of this paper. We also appreciate greatly the numerous constructive suggestions made by our editor, Professor Dilling, and our anonymous reviewers.

\section{REFERENCES}

Agutu, N., J. Awange, A. Zerihun, C. Ndehedehe, M. Kuhn, and Y. Fukuda, 2017: Assessing multi-satellite remote sensing, reanalysis, and land surface models' products in characterizing agricultural drought in East Africa. Remote Sens. Environ., 194, 287-302, https://doi.org/10.1016/j.rse.2017.03.041.

Bekele-Biratu, E., W. M. Thiaw, and D. Korecha, 2018: Sub-seasonal variability of the Belg rains in Ethiopia. Int. J. Climatol., 38, 2940-2953, https://doi .org/10.1002/joc.5474.

Brown, J. F., D. Howard, B. Wylie, A. Frieze, L. Ji, and C. Gacke, 2015: Application-ready expedited MODIS data for operational land surface monitoring of vegetation condition. Remote Sens., 7, 16226-16240, https://doi.org/10.3390/rs71215825.

Brown, M. E., 2008: Famine Early Warning Systems and Remote Sensing Data. Springer, 314 pp., https://doi .org/10.1007/978-3-540-75369-8.

— , and Coauthors, 2015: Climate change, global food security, and the U.S. food system. USDA 
Tech. Doc., U.S. Global Change Research Program, 146 pp., www.usda.gov/oce/climate_change /FoodSecurity2015Assessment/FullAssessment.pdf. Checchi, F., and W. C. Robinson, 2013: Mortality among populations of southern and central Somalia affected by severe food insecurity and famine during 2010-2012. FEWS NET, 87 pp., www.fsnau.org /downloads/Somalia_Mortality_Estimates_Final _Report_8May2013_upload.pdf.

Davenport, F., K. Grace, C. Funk, and S. Shukla, 2017: Child health outcomes in sub-Saharan Africa: A comparison of changes in climate and socioeconomic factors. Global Environ. Change, 46, 72-87, https://doi.org/10.1016/j.gloenvcha.2017.04.009.

—, C. Funk, and G. Galu, 2018: How will East African maize yields respond to climate change and can agricultural development mitigate this response? Climatic Change, 147, 491-506, https://doi .org/10.1007/s10584-018-2149-7.

Derber, J. C., D. F. Parrish, and S. J. Lord, 1991: The new global operational analysis system at the National Meteorological Center. Wea. Forecasting, 6, 538-547, https://doi.org/10.1175/1520-0434(1991) 006<0538:TNGOAS>2.0.CO;2.

Ek, M., and Coauthors, 2003: Implementation of Noah land surface model advances in the National Centers for Environmental Prediction operational mesoscale Eta model. J. Geophys. Res., 108, 8851, https://doi .org/10.1029/2002JD003296.

Falkenmark, M., 1989: The massive water scarcity now threatening Africa: Why isn't it being addressed? Ambio, 18, 112-118.

FAO, IFAD, UNICEF, WFP, and WHO, 2017: The state of food security and nutrition in the world 2017: Building resilience for peace and food security. FAO, 117 pp., www.fao.org/3/a-I7695e.pdf.

FEWS NET, 2018: Hunger-related mortality likely as IPC phase 4 outcomes and large-scale assistance needs persist. FEWS NET, https://fews.net/sites /default/files/Food_assistance_peak_needs_2019 .pdf?platform=hootsuite.

FFP, 2018: Food for peace year in review. Food for Peace, USAID, 30 pp., www.usaid.gov/sites/default /files/documents/1866/FY17_Annual_Report _FINAL_508_compliant.pdf.

Funk, C., 2011: We thought trouble was coming. Nature, 476, https://doi.org/10.1038/476007a.

—_, and J. P. Verdin, 2009: Real-time decision support systems: The Famine Early Warning System Network. Satellite Rainfall Applications for Surface Hydrology, M. Gebremichael and F. Hossain, Eds., Springer, 295-320, https://doi.org/10.1007/978-90 -481-2915-7_17.
— and CMIP5 ENSO-residual sea surface temperatures and associated changes in Indo-Pacific climate. J. Climate, 28, 4309-4329, https://doi.org/10.1175 /JCLI-D-14-00334.1.

- , and — 2017: Recent climate extremes associated with the West Pacific Warming Mode. Climate Extremes: Patterns and Mechanisms, Geophys. Monogr., Vol. 226, Amer. Geophys. Union, 165-175, https://doi .org/10.1002/9781119068020.ch10.

_ - and Coauthors, 2005: Recent drought tendencies in Ethiopia and equatorial-subtropical eastern Africa. Vulnerability to Food Insecurity: Factor Identification and Characterization Report, Rep. 01/2005, U.S. Agency for International Development, $12 \mathrm{pp}$.

—, A. Hoell, S. Shukla, I. Bladé, B. Liebmann, J. B. Roberts, and G. Husak, 2014: Predicting East African spring droughts using Pacific and Indian Ocean sea surface temperature indices. Hydrol. Earth Syst. Sci., 18, 4965-4978, https://doi.org/10.5194/hess-18 $-4965-2014$.

—, S. E. Nicholson, M. Landsfeld, D. Klotter, P. Peterson, and L. Harrison, 2015a: The centennial trends greater Horn of Africa precipitation dataset. Sci. Data, 2, 150050, https://doi.org/10.1038/sdata.2015.50. — , and Coauthors, 2015b: The climate hazards infrared precipitation with stations-A new environmental record for monitoring extremes. Sci. Data, 2, 150066, https://doi.org/10.1038/sdata.2015.66.

—, L. Harrison, S. Shukla, A. Hoell, D. Korecha, T. Magadzire, G. Husak, and G. Galu, 2016: Assessing the contributions of local and east Pacific warming to the 2015 droughts in Ethiopia and southern Africa [in "Explaining Extreme Events of 2015 from a Climate Perspective"]. Bull. Amer. Meteor. Soc., 97 (12), S75-S77, https://doi.org/10.1175/BAMS -D-16-0167.1.

— , and Coauthors, 2018a: Examining the role of unusually warm Indo-Pacific sea surface temperatures in recent African droughts. Quart. J. Roy. Meteor. Soc., 144, 360-383, https://doi.org/10.1002/qj.3266.

— ment of moderate-to-strong El Niño events likely contributed to drought and poor harvests in southern Africa during 2016 [in "Explaining Extreme Events of 2016 from a Climate Perspective"]. Bull. Amer. Meteor. Soc., 99 (1), S91-S96, https://doi .org/10.1175/BAMS-D-17-0112.1.

_ , F. Davenport, G. Eilerts, N. Nourey, and G. Galu, 2018c: Contrasting Kenyan resilience to drought: 2011 and 2017. USAID Special Rep., 20 pp., www.usaid .gov/resilience/contrasting-kenyan-resilience -drought-2011-2017. 
,,,---- , and,$- 2018 \mathrm{~d}$ : Contrasting Kenyan resilience to food insecurity: 2011 and 2017. USAID Special Rep., 16 pp., www.usaid.gov /documents/1867/contrasting-kenyan-resilience -drought-2011-2017.

— and Coauthors, 2019: Examining the potential contributions of extreme "Western V" sea surface temperatures to the 2017 March-June East African drought [in "Explaining Extreme Events of 2017 from a Climate Perspective"]. Bull. Amer. Meteor. Soc., 100 (1), S55-S60, https://doi.org/10.1175/BAMS-D-18-0108.1.

Giannini, A., B. Lyon, R. Seager, and N. Vigaud, 2018: Dynamical and thermodynamic elements of modeled climate change at the East African margin of convection. Geophys. Res. Lett., 45, 992-1000, https:// doi.org/10.1002/2017GL075486.

Hillbruner, C., and G. Moloney, 2012: When early warning is not enough-Lessons learned from the 2011 Somalia Famine. Global Food Secur., 1, 20-28, https://doi.org/10.1016/j.gfs.2012.08.001.

Hoell, A., and C. Funk, 2013: The ENSO-related west Pacific sea surface temperature gradient. $J$. Climate, 26, 9545-9562, https://doi.org/10.1175 /JCLI-D-12-00344.1.

$\longrightarrow$, and —_, 2014: Indo-Pacific sea surface temperature influences on failed consecutive rainy seasons over eastern Africa. Climate Dyn., 43, 1645-1660, https://doi.org/10.1007/s00382-013-1991-6.

—_ _ - and M. Barlow, 2014: La Niña diversity and northwest Indian Ocean rim teleconnections. Climate Dyn., 43, 2707-2724, https://doi.org/10.1007 /s00382-014-2083-y.

—_ — - T. Magadzire, J. Zinke, and G. Husak, 2015: El Niño-Southern Oscillation diversity and southern Africa teleconnections during austral summer. Climate Dyn., 45, 1583-1599, https://doi.org/10.1007 /s00382-014-2414-z.

_,$\ldots$, J. Zinke, and L. Harrison, 2017a: Modulation of the southern Africa precipitation response to the $\mathrm{El}$ Niño Southern Oscillation by the subtropical Indian Ocean Dipole. Climate Dyn., 48, 2529-2540, https:// doi.org/10.1007/s00382-016-3220-6.

- , M. Hoerling, J. Eischeid, X.-W. Quan, and B. Liebmann, 2017b: Reconciling theories for human and natural attribution of recent East Africa drying. J. Climate, 30, 1939-1957, https://doi.org/10.1175 /JCLI-D-16-0558.1.

Jung, H. C., A. Getirana, F. Policelli, A. McNally, K. R. Arsenault, S. Kumar, T. Tadesse, and C. D. Peters-Lidard, 2017: Upper Blue Nile basin water budget from a multi-model perspective. J. Hydrol., 555, 535-546, https://doi.org/10.1016/j.jhydrol.2017 .10 .040 .
Kogan, F., 2002: World droughts in the new millennium from AVHRR-based vegetation health indices. Eos, Trans. Amer. Geophys. Union, 83, 557-563, https:// doi.org/10.1029/2002EO000382.

Korecha, D., and A. G. Barnston, 2007: Predictability of June-September rainfall in Ethiopia. Mon. Wea. Rev., 135, 628-650, https://doi.org/10.1175/MWR3304.1.

Kumar, S. V., and Coauthors, 2006: Land information system: An interoperable framework for high resolution land surface modeling. Environ. Modell. Software, 21, 1402-1415, https://doi.org/10.1016/j .envsoft.2005.07.004.

Liang, X., D. P. Lettenmaier, E. F. Wood, and S. J. Burges, 1994: A simple hydrologically based model of land surface water and energy fluxes for general circulation models. J. Geophys. Res., 99, 14 415-14428, https://doi.org/10.1029/94JD00483.

Lyon, B., and D. G. DeWitt, 2012: A recent and abrupt decline in the East African long rains. Geophys. Res. Lett., 39, L02702, https://doi.org/10 .1029/2011GL050337.

Magadzire, T., G. Galu, and J. Verdin, 2017: How climate forecasts strengthen food security. WMO Bull., 66 (2), https://public.wmo.int/en/resources /bulletin/how-climate-forecasts-strengthen-food -security.

McNally, A., and Coauthors, 2015: Calculating crop water requirement satisfaction in the West Africa Sahel with remotely sensed soil moisture. J. Hydrometeor., 16, 295-305, https://doi.org/10.1175 /JHM-D-14-0049.1.

—, S. Shukla, K. R. Arsenault, S. Wang, C. D. PetersLidard, and J. P. Verdin, 2016: Evaluating ESA CCI soil moisture in East Africa. Int. J. Appl. Earth Obs. Geoinf., 48, 96-109, https://doi.org/10.1016/j .jag.2016.01.001.

—-, and Coauthors, 2017: A land data assimilation system for sub-Saharan Africa food and water security applications. Sci. Data, 4, 170012, https://doi .org/10.1038/sdata.2017.12.

Nicholson, S. E., 1986: The nature of rainfall variability in Africa south of the equator. J. Climatol., 6, 515-530, https://doi.org/10.1002/joc.3370060506.

Nijssen, B., and Coauthors, 2014: A prototype global drought information system based on multiple land surface models. J. Hydrometeor., 15, 1661-1676, https://doi.org/10.1175/JHM-D-13-090.1.

Novella, N. S., and W. M. Thiaw, 2013: African rainfall climatology version 2 for famine early warning systems. J. Appl. Meteor. Climatol., 52, 588-606, https:// doi.org/10.1175/JAMC-D-11-0238.1.

- , and _ 2016: A seasonal rainfall performance probability tool for famine early warning systems. $J$. 
Appl. Meteor. Climatol., 55, 2575-2586, https://doi .org/10.1175/JAMC-D-16-0111.1.

Pomposi, C., C. Funk, S. Shukla, L. Harrison, and T. Magadzire, 2018: Distinguishing southern Africa precipitation response by strength of El Niño events and implications for decision-making. Environ. Res. Lett., 13, 074015, https://doi.org/10.1088/1748-9326 /aacc4c.

Pozzi, W., and Coauthors, 2013: Toward global drought early warning capability: Expanding international cooperation for the development of a framework for monitoring and forecasting. Bull. Amer. Meteor. Soc., 94, 776-785, https://doi.org/10.1175/BAMS -D-11-00176.1.

Ratnam, J. V., S. K. Behera, Y. Masumoto, and T. Yamagata, 2014: Remote effects of El Niño and Modoki events on the austral summer precipitation of southern Africa. J. Climate, 27, 3802-3815, https:// doi.org/10.1175/JCLI-D-13-00431.1.

Reason, C., R. Allan, J. Lindesay, and T. Ansell, 2000: ENSO and climatic signals across the Indian Ocean basin in the global context: Part I, Interannual composite patterns. Int. J. Climatol., 20, 1285-1327, https://doi.org/10.1002/1097 -0088(200009)20:11<1285::AID-JOC536>3.0.CO ;2-R.

Rowell, D. P., B. B. B. Booth, S. E. Nicholson, and P. Good, 2015: Reconciling past and future rainfall trends over East Africa. J. Climate, 28, 9768-9788, https://doi.org/10.1175/JCLI-D-15-0140.1.

Schneider, U., P. Finger, A. Meyer-Christoffer, E. Rustemeier, M. Ziese, and A. Becker, 2017: Evaluating the hydrological cycle over land using the newly-corrected precipitation climatology from the Global Precipitation Climatology Centre (GPCC). Atmosphere, 8, 52, https://doi.org/10.3390 /atmos8030052.

Sen, A., 1981: Poverty and Famines: An Essay on Entitlement and Deprivation. Oxford University Press, 270 pp.

Senay, G. B., and J. Verdin, 2003: Characterization of yield reduction in Ethiopia using a GIS-based crop water balance model. Can. J. Remote Sens., 29, 687-692, https://doi.org/10.5589/m03-039.

—, M. Budde, J. P. Verdin, and A. M. Melesse, 2007: A coupled remote sensing and Simplified Surface Energy Balance approach to estimate actual evapotranspiration from irrigated fields. Sensors, 7, 979-1000, https://doi.org/10.3390/s7060979.

,$- \ldots$, and — 2011: Enhancing the Simplified Surface Energy Balance (SSEB) approach for estimating landscape ET: Validation with the METRIC model. Agric. Water Manage., 98, 606-618, https:// doi.org/10.1016/j.agwat.2010.10.014.
—, S. Bohms, R. K. Singh, P. H. Gowda, N. M. Velpuri, H. Alemu, and J. P. Verdin, 2013: Operational evapotranspiration mapping using remote sensing and weather datasets: A new parameterization for the SSEB approach. J. Amer. Water Resour. Assoc., 49, 577-591, https://doi.org/10.1111/jawr.12057.

Sheffield, J., and Coauthors, 2014: A drought monitoring and forecasting system for sub-Sahara African water resources and food security. Bull. Amer. Meteor. Soc., 95, 861-882, https://doi.org/10.1175/BAMS -D-12-00124.1.

Shukla, S., C. Funk, and A. Hoell, 2014a: Using constructed analogs to improve the skill of MarchApril-May precipitation forecasts in equatorial East Africa. Environ. Res. Lett., 9, 094009, https://doi .org/10.1088/1748-9326/9/9/094009.

—, A. McNally, G. Husak, and C. Funk, 2014b: A seasonal agricultural drought forecast system for food-insecure regions of East Africa. Hydrol. Earth Syst. Sci., 18, 3907-3921, https://doi.org/10.5194 /hess-18-3907-2014.

Svoboda, M., and Coauthors, 2002: The Drought Monitor. Bull. Amer. Meteor. Soc., 83, 1181-1190, https://doi.org/10.1175/1520-0477-83.8.1181.

Tapley, B. D., S. Bettadpur, M. Watkins, and C. Reigber, 2004: The Gravity Recovery and Climate Experiment: Mission overview and early results. Geophys. Res. Lett., 31, L09607, https://doi.org /10.1029/2004GL019920.

Thiaw, W. M., and V. B. Kumar, 2015: NOAA's African desk: Twenty years of developing capacity in weather and climate forecasting in Africa. Bull. Amer. Meteor. Soc., 96, 737-753, https://doi.org/10.1175/BAMS -D-13-00274.1.

Tippett, M. K., M. Ranganathan, M. L'Heureux, A. G. Barnston, and T. DelSole, 2017: Assessing probabilistic predictions of ENSO phase and intensity from the North American Multimodel Ensemble. Climate Dyn., https://doi.org/10.1007/s00382-017 -3721-y, in press.

Verdin, J., and R. Klaver, 2002: Grid-cell-based crop water accounting for the famine early warning system. Hydrol. Processes, 16, 1617-1630, https://doi .org/10.1002/hyp.1025.

—, C. Funk, G. Senay, and R. Choularton, 2005: Climate science and famine early warning. Philos. Trans. Roy. Soc. London, 360B, 2155-2168, https:// doi.org/10.1098/rstb.2005.1754.

Wu, H., R. F. Adler, Y. Tian, G. J. Huffman, H. Li, and J. Wang, 2014: Real-time global flood estimation using satellite-based precipitation and coupled land surface and routing model. Water Resour. Res., 50, 2693-2717, https://doi.org/10.1002/2013WR014710. 


\section{AMS Publications introduces}

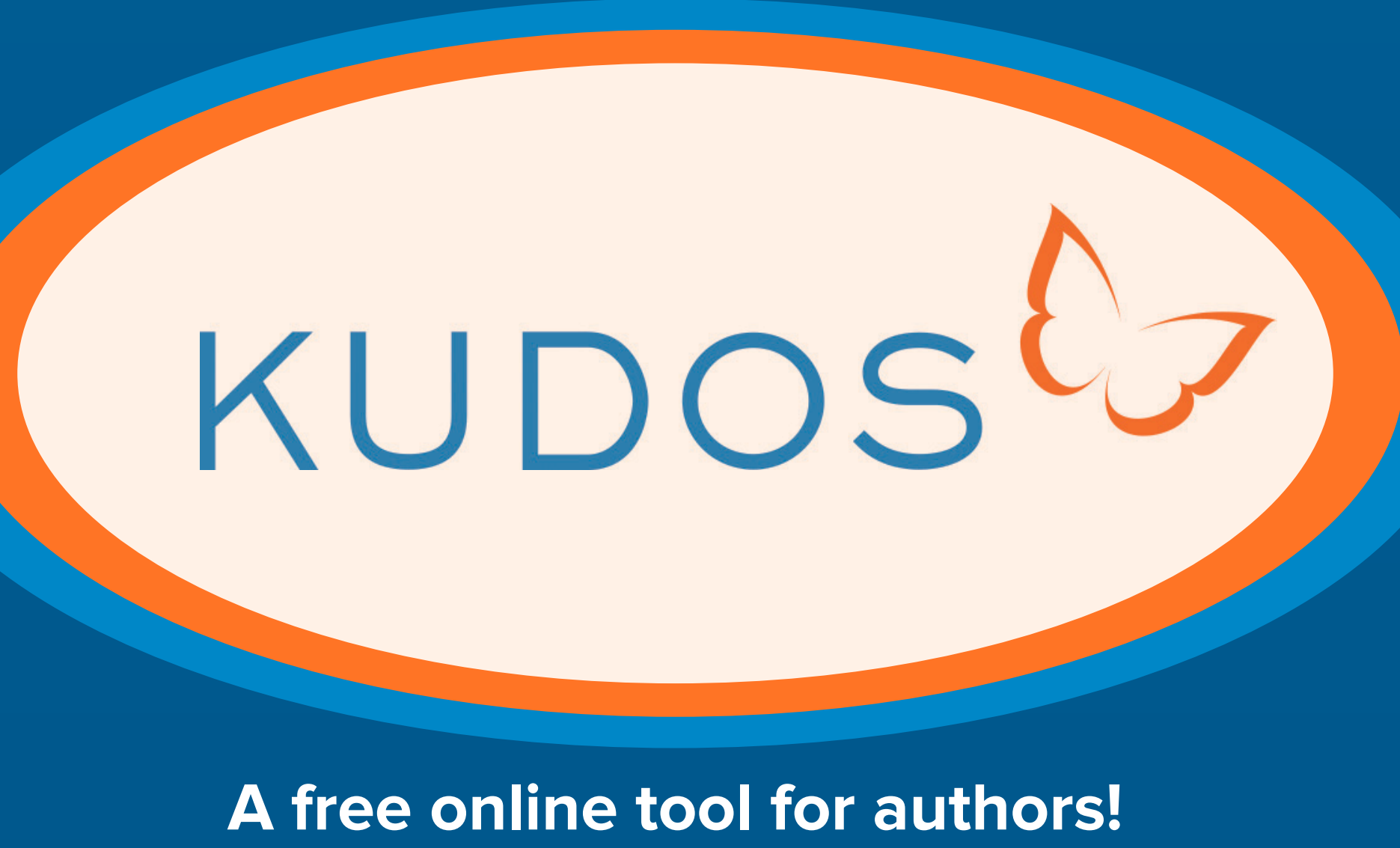

Communicate Your Research More Effectively

\section{Increase Your Work's Impact}

- Maximize citations and downloads of your article

- Open up your research to new audiences

- Explain and share your work in only 10 minutes

- Increase full-text article downloads by $23 \%$

- Access publication metrics via the author dashboard

Learn more about using Kudos with AMS

https://www.ametsoc.org/kudos/ 